\title{
Introduksi Teknologi Pengolahan Kacang Koro Pedang dalam Rangka Inisiasi Sentra Olahannya di Desa Tahai Baru Kalimantan Tengah
}

\author{
Introduction of Jake Beans Processing Technology in the Framework of Initiation of Processed \\ Centers in the Village of Tahai Baru, Central Kalimantan
}

Sih Winarti ${ }^{1}$
Wijantri Kusumadati ${ }^{2}$
Hastin Ernawati Nur Chusnul
Chotimah ${ }^{*}$
Gusti Irya Ichriani ${ }^{3}$
1Department of Environmental
Science, Universitas Palangka Raya,
Palangka Raya, Central Kalimantan,
Indonesia
2Department of Food Technology,
Universitas Palangka Raya, Palangka
Raya, Central Kalimantan, Indonesia
3Department of Agrotechnology,
Universitas Palangka Raya, Palangka
Raya, Central Kalimantan, Indonesia
Keceived: December 2019
Accepted: February 2020
Published: June 2020
Jake Beans
Processing
Packaging
Village center
Kata Kunci hastinwindarto@agr.upr.ac.id
Pangkordang
Pengolahan
Desa sentra

\begin{abstract}
Abstrak
Desa Tahai Baru merupakan salah satu desa di Kecamatan Maliku, Kabupaten Pulang Pisau, Kalimantan Tengah yang mendapat bantuan dana untuk pelaksanaan kegiatan budidaya kacang koro pedang (cangkordang) melalui program Kelompok Usaha Bersama (KUBE) Program Keluarga Harapan (PKH). Pelatihan dan pendampingan perlu dilakukan mengingat masyarakat desa Tahai Baru belum mempunyai pengetahuan dan keterampilan serta belum mengetahui teknologinya. Tujuan kegiatan ini adalah meningkatkan pengetahuan dan keterampilan masyarakat Desa Tahai Baru Kecamatan Maliku Kabupaten Pulang Pisau dalam melihat alternatif pemanfaatan sumberdaya alam khususnya cangkordang serta meningkatkan pendapatan masyarakat melalui kegiatan pengolahan dan pengemasan produk olahan cangkordang. Beberapa pendekatan dilakukan melalui metode penyuluhan, pelatihan, pendampingan, ekspose kegiatan dan evaluasi keberlanjutan dan keberhasilan program. Hasil kegiatan menunjukkan masyarakat desa Tahai Baru sudah memiliki pengetahuan dan keterampilan tentang pengolahan cangkordang serta telah melakukan pemasaran beberapa produk olahan cangkordang. Pelaksanaan Program Pengembangan Desa Mitra diharapkan mampu membawa dampak perubahan terhadap peningkatan kesejahteraan sosial anggota KUBE PKH dan terjalin kemitraan yang berkesinambungan antara Desa Tahai Baru dan Universitas Palangka Raya.
\end{abstract}

\begin{abstract}
Tahai Baru Village is one of the villages in Maliku Subdistrict, Pulang Pisau Regency, Central Kalimantan, which received funding for the implementation of the koro sword (cangkordang) cultivation activities through the Joint Family Business Program (KUBE) program (PKH). Training and assistance need to be done considering that the Tahai Baru village community does not yet have the knowledge and skills and do not yet know the technology. The purpose of this activity is to increase the knowledge and skills of the people of Tahai Baru Village, Maliku District, Pulang Pisau Regency, in seeing alternative uses of natural resources, especially cangkordang, and increasing community income through processing and packaging of processed cangkordang products. Some approaches are carried out through counseling, training, mentoring, exposure of activities and evaluating the sustainability and success of the program. The results of the activity showed that the community of Tahai Baru village had knowledge and skills about processing cangkordang and marketing several processed cangkordang products. The implementation of the Mitra Desa Development Program is expected to be able to bring a change in the impact on improving the social welfare of KUBE PKH members and establishing a sustainable partnership between Tahai Baru Village and Palangka Raya University.
\end{abstract}




\section{PENDAHULUAN}

Kekayaan dan investasi masyarakat pedesaan tidak dinilai dari berapa jumlah uang yang berada di tabungan akan tetapi dinilai dari berapa kepemilikan properti dan kekayaan hayati yang mereka miliki. Potensi kekayaan tersebut akan berdaya saing dan berpotensi dikembangkan karena berkaitan erat dengan kehidupan manusia (Indratno \& Agustina 2005). Sebagai bentuk kepedulian terhadap penanganan percepatan perekonomian desa, Lembaga Penelitian dan Pengabdian Kepada Masyarakat Universitas Palangka Raya memberikan kontribusi nyata penguatan aplikasi teknologi berbasis riset melalui Program Desa Mitra untuk memberikan solusi salah satu permasalahan desa Tahai Baru tentang penciptaan nilai tambah produk cangkordang.

Desa Tahai Baru kecamatan Maliku kabupaten Pulang Pisau Kalimantan Tengah, merupakan salah satu desa penerima bantuan Usaha Budidaya Kacang Koro Pedang (Cangkordang) (Canavalia ensiformis) dari Dinas Sosial melalui program KUBE (Kelompok Usaha Bersama) PKH (Program Keluarga Harapan) guna menanggulangi kemiskinan serta memberikan modal usaha untuk mengelola Usaha Ekonomi Produktif (UEP) dengan tujuan meningkatkan pendapatan masyarakat desa Tahai Baru. Pemilihan jenis usaha budidaya cangkordang dilatarbelakangi oleh ketersediaan sumberdaya yang ada yaitu melimpahnya lahan dan kondisi alam yang mendukung. Cangkordang merupakan tanaman kacang-kacangan yang mudah dibudidayakan secara monokultur atau tumpang sari, adaptif pada lahan marjinal, kandungan antioksidan lebih tinggi, penghasil pupuk hijau dan harganya lebih murah daripada kedelai (Diniyah et al., 2014). Usaha budidaya ini berkontribusi pada diversifikasi olahan pangan non kedelai. Selain itu, mengingat produksi kedelai nasional belum bisa mencukupi kebutuhan pangan, maka diversifikasi olahan kacang lokal menjadi alternatif bagi masyarakat untuk melakukan usaha berbasis komoditi lokal yang nilai gizi dan citarasanya tidak kalah dengan kedelai (Ekafitri \& Isworo, 2014; Azahari, 2016).

Perolehan bantuan untuk budidaya cangkordang tersebut menyebabkan mereka sedikit kebingungan untuk meningkatkan nilai jual dari hasil budidaya cangkordang tersebut. Keterbatasan pengetahuan dan keterampilan serta teknologi dalam mengolah hasil panen cangkordang menjadi kendala utama (Ginting, 2002). Transfer teknologi yang pernah dilakukan oleh Pemerintah Daerah baru sebatas pendampingan teknis budidayanya, belum untuk teknologi pengolahan dan teknologi mengakses pasar. Pengolahan yang mereka lakukan baru sebatas pada pengolahan hasil menjadi tempe koro, namun kualitas tempe yang dihasilkan dinilai mereka masih kurang bermutu dan berkualitas, bahkan beberapa kali mereka mengalami kegagalan dalam menghasilkan olahan tempe tersebut (Husniah et al., 2019).

Pengemasan juga belum dilakukan dikarenakan terbatasnya informasi dan pengetahuan terhadap berbagai hal yang terkait pengemasan (Alsuhendra \& Ridawati, 2017). Selain itu terdapat ketakutan di benak masyarakat dikarenakan di dalam biji cangkordang terdapat kandungan sianida sehingga harus ada teknologi pengolahan yang tepat dan benar untuk bisa mengolahnya menjadi produk makanan ataupun minuman seperti halnya produk-produk yang telah dihasilkan oleh daerah lain. Oleh karena itu diperlukan kerja sama antara masyarakat desa, civitas akademika dan pemerintah untuk menentukan upaya peningkatan nilai tambah hasil cangkordang melalui pengolahan pascapanen yang tepat (Dacholfany, 2018). Hasil program pemberdayaan masyarakat melalui diversifikasi pengolahan hasil panen tanaman 
cangkordang diharapkan mampu memberikan solusi terhadap peningkatan pendapatan dan kesejahteraan masyarakat Desa Tahai Baru.

Permasalahan yang dihadapi oleh masyarakat Desa Tahai Baru adalah Masyarakat desa Tahai Baru belum mempunyai keterampilan dan pemahaman teknologi untuk memanfaatkan cangkordang sebagai produk olahan pangan dan Penanganan bahan baku cangkordang supaya aman konsumsi untuk produk olahan pangan belum diketahui dan dipahami masyarakat. Tujuan dari kegiatan ini adalah meningkatkan pengetahuan dan keterampilan masyarakat Desa Tahai Baru Kecamatan Maliku Kabupaten Pulang Pisau dalam pemanfaatan cangkordang untuk produk olahan pangan, meningkatkan hubungan kemitraan antara kampus Universitas Palangka Raya dengan masyarakat dan pemerintah Kabupaten Pulang Pisau, dan meningkatkan pendapatan masyarakat melalui kegiatan pengolahan dan pengemasan produk olahan cangkordang.

\section{METODOLOGI}

Kegiatan pengabdian kepada masyarakat dalam bentuk Program Pengembangan Desa Mitra (PPDM) ini dilaksanakan di Desa Tahai Baru, Kecamatan Maliku Kabupaten Pulang Pisau. Pelaksanaan program ini dilakukan mulai bulan Juni - November 2019. Kegiatan PPDM di Desa Tahai Baru menyasar ibu-ibu yang berasal dari Program Keluarga Harapan (PKH) dan tergabung dalam Kelompok Usaha Bersama Ekonomi (KUBE). Adanya 2 KUBE yang terlibat kegiatan yaitu KUBE Barokahi (Ketua Umi Hidayah) dan KUBE Mawar (Ketua Sunarti). Masing-masing KUBE terdiri atas 10 orang ibu-ibu anggota.

Kegiatan PPDM ini berupaya untuk mengatasi permasalahan penanganan hasil panen kacang koro pedang di Desa Tahai Baru. Kegiatan yang dilakukan sesuai kesepakatan bersama antara 2 KUBE dengan Tim Pelaksana PPDM. Adapun rangkaian kegiatan PPDM dapat dilihat pada Gambar 1.

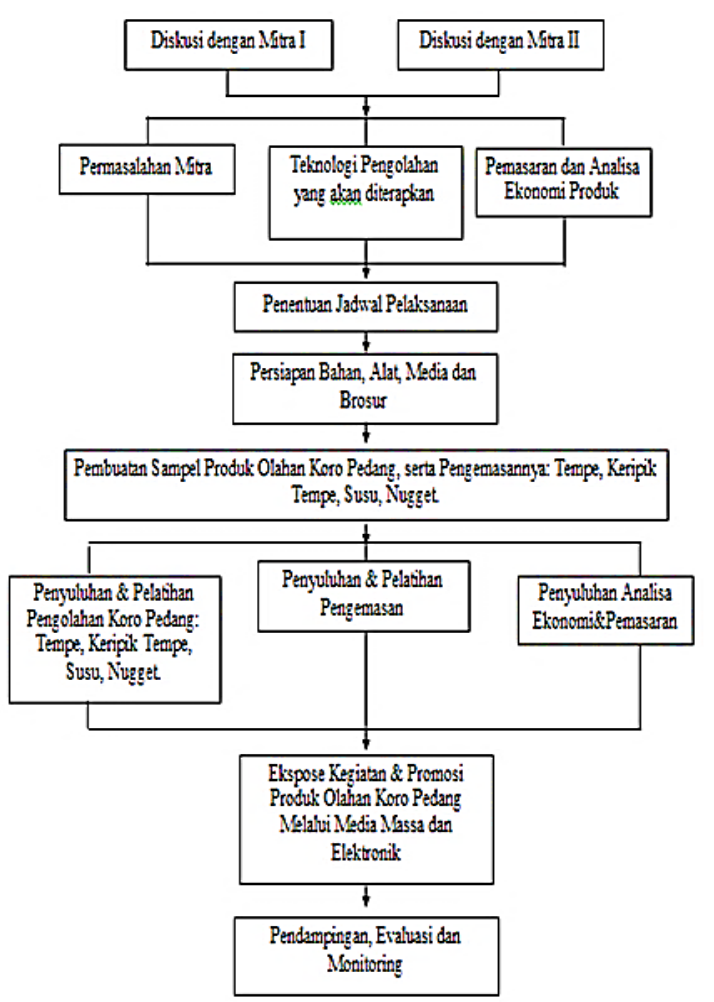

Gambar 1. Alur Kegiatan Program Pengembangan Desa Mitra (PPDM) di Desa Tahai Baru

Berdasarkan pada prioritas permasalahan mitra, maka solusi yang dapat ditawarkan dari hasil diskusi dengan KUBE Barokahi dan KUBE Mawar adalah sebagai berikut:

1. Meningkatkan nilai tambah dari hasil budidaya kacang koro pedang dengan cara menghasilkan produk olahannya yang bermutu baik.

2. Menghasilkan manual teknologi pengolahan dan pengemasan hasil olahan kacang koro pedang.

3. Mempromosikan Desa Tahai Baru melalui presentasi hasil-hasil kegiatan baik dalam bentuk presentasi oral maupun poster.

4. Mempublikasikan hasil kegiatan dalamjurnal ilmiah, media cetak, elektronik dan online. 
5. Membantu pembentukan jejaring antara masyarakat usaha di Desa Tahai Baru dengan lembaga keuangan mikro setempat.

\section{HASIL DAN PEMBAHASAN}

\section{Penyuluhan}

Kelompok mitra memiliki pengalaman terkait produk olahan pangan selain cangkordang yaitu kripik singkong dan kripik pisang. Umumnya produk olahan pangan diproduksi hanya untuk dikonsumsi sendiri. Ada yang menjual produksinya, akan tetapi area pemasarannya hanya lingkungan desa. Kelompok mitra belum pernah memproduksi produk olahan cangkordang. Pada saat kegiatan penyuluhan, sampel produk olahan cangkordang diperlihatkan kepada kelompok mitra. Sambutan mereka sangat antusias ingin mempelajari cara memproduksi produk, mengetahui cara pengemasan dan pelabelan produk yang baik.
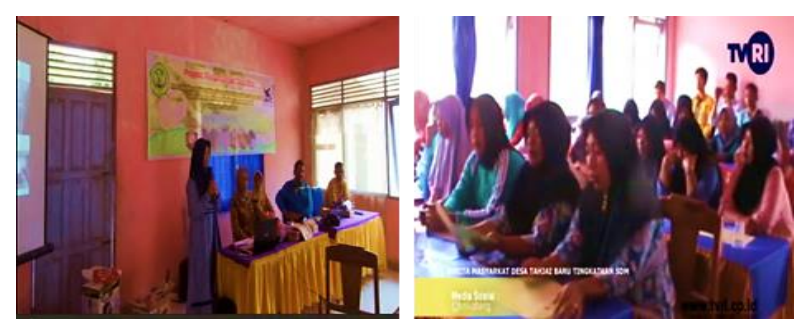

Gambar 2. Kegiatan penyuluhan PPDM di Desa Tahai Baru Kec. Maliku Kab. Pulang Pisau

\section{Pelatihan}

Pelatihan dilakukan dengan melakukan praktik pengolahan hasil olahan kacang koro pedang berupa tempe, keripik tempe, kacang koro pedang (cangkordang), nugget, dan susu serta pengemasannya seperti ditunjukkan pada Gambar 3.

Produk yang dihasilkan mitra perlu dikemas agar dapat dipasarkan. Produk yang dihasilkan mitra perlu dikemas agar dapat dipasarkan. Pengemasan dapat membantu supaya produk yang dibuat tetap bersih dari berbagai kotoran, pencemaran, maupun adanya kerusakan terhadap fisik produk dan oksidasi produk (Herawati, 2008).

Pada kegiatan ini mitra dikenalkan beberapa bahan kemasan, alat pengemas, dan kegunaannya. Mitra dilatih untuk dapat mengemas aneka produk olahan koro pedang menggunakan peralatan yang diberikan sesuai jenis produknya. Keripik tempe koro dikemas dalam standing pouch dengan ketebalan $0,8 \mathrm{~mm}$ dan diseal. Nugget koro dikemas vacuum dalam plastik PP ketebalan 0,8 mm menggunakan vacuum sealer. Susu kacang koro pedang dikemas menggunakan gelas dan ditutup menggunakan cup sealer. Pelabelan hanya diperkenalkan kepada mitra karena keterbatasan waktu untuk pelatihan.
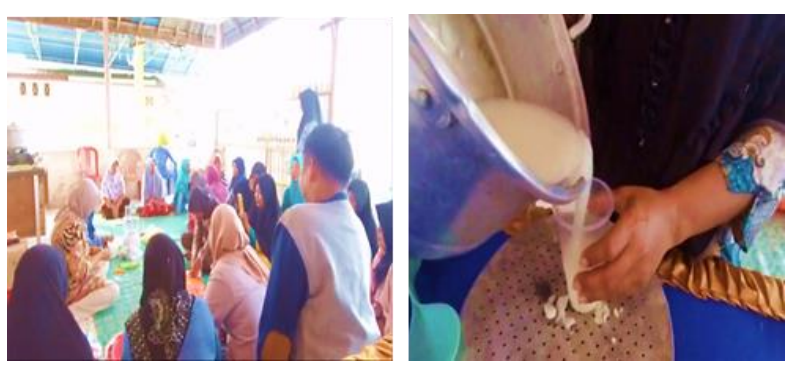

Gambar 3. Suasana kegiatan pelatihan pembuatan olahan pangan berbasis cangkordang di Desa Tahai Baru Kec. Maliku Kab. Pulang Pisau

Pelaksanaan PPDM Desa Tahai Baru telah dipublikasikan melalui beberapa portal media sebagai berikut:

1. Program Pengembangan Desa Mitra I Introduksi Kacang Koro di Desa Tahai, Kalimantan Tengah, www.youtube.com, https://youtu.be/CPSKb0Tv1rE (liputan TVRI)

2. Wakil Rakyat Apresiasi Ibu-ibu di KUBE PKH Sinar Makmur

https://www.kanalkalimantan.com/kube-pkhsinar-makmur-sukses-kembangan-olahan-kacangkoro-pedang/ 


\section{Pendampingan}

Kunci pemanfaatan cangkordang untuk produk olahan pangan adalah penanganan yang bahan baku cangkordang. Bahan baku cangkordang memiliki kandungan sianida. Teknik penanganan yang tidak tepat mengakibatkan produk olahan yang dihasilkan menjadi tidak aman untuk dikonsumsi. Adanya kandungan sianida dalam cangkordang dapat menyebabkan rasa gatal di mulut. Pada kasus yang lebih parah, dapat menyebabkan pusing.

Pemantauan, pembinaan dan evaluasi seperti ditunjukkan pada Gambar 2 dilaksanakan selama dua bulan. Dari kegiatan PPDM, kelompok mitra mengetahui pengolahan cangkordang yang benar (100\%) dan mampu menghasilkan produk olahan cangkordang keripik tempe sebesar 94,7\%. Sebelum kegiatan PPDM dilaksanakan, semua anggota mitra tidak mengetahui adanya kandungan asam sianida pada cangkordang dan cara penanganannya. Setelah kegiatan PPDM dilaksanakan di desa ini, kelompok mitra menjadi paham dan sehingga tidak ada kekhawatiran lagi menjadi pusing dan adanya rasa gatal jika mengkonsumsi produk cangkordang.

Dalam waktu hampir satu bulan mitra sudah mencoba membuat produk olahan berupa kripik tempe cangkordang. Keripik tempe yang diproduksi tidak lagi hanya konsumsi, tetapi telah $100 \%$ dijual. Informasi yang diberikan Ibu Umi (Ketua KUBE Barokahi) bahwa mereka telah 2 kali memproduksi tempe dengan bahan baku cangkordang masing-masing $3 \mathrm{~kg}$ dan $2 \mathrm{~kg}$. Dari 3 $\mathrm{kg}$ bahan baku cangkordang diperoleh 30 bungkus kemasan keripik tempe, dan dari $2 \mathrm{~kg}$ menghasilkan 15 bungkus kemasan keripik tempe. Keripik yang dihasilkan cukup renyah dan disukai konsumen. Produk keripik tempe mitra juga telah diikutsertakan pada Jambore PKK Kabupaten Pulang Pisau pada tanggal 25 Oktober 2019. Keripik tempe Desa Tahai Baru menjadi sebagai salah satu produk unggulan Kecamatan Maliku.

Keterampilan pengemasan produk olahan cangkordang sudah dipahami mitra sebesar 84,2\%. Mitra kurang paham $(15,8 \%)$ pada proses pengemasan menggunakan vacuum sealer untuk produk nugget. Anggota mitra yang belum paham rata-rata sudah berusia lanjut, mengingat pada teknik pengemasan vacuum memerlukan ketelatenan dalam membantu mengeluarkan udara dalam kemasan dan adanya dua tombol yang harus ditekan bergantian dengan cepat. Namun hal ini tidak menyurutkan mereka untuk terus belajar.

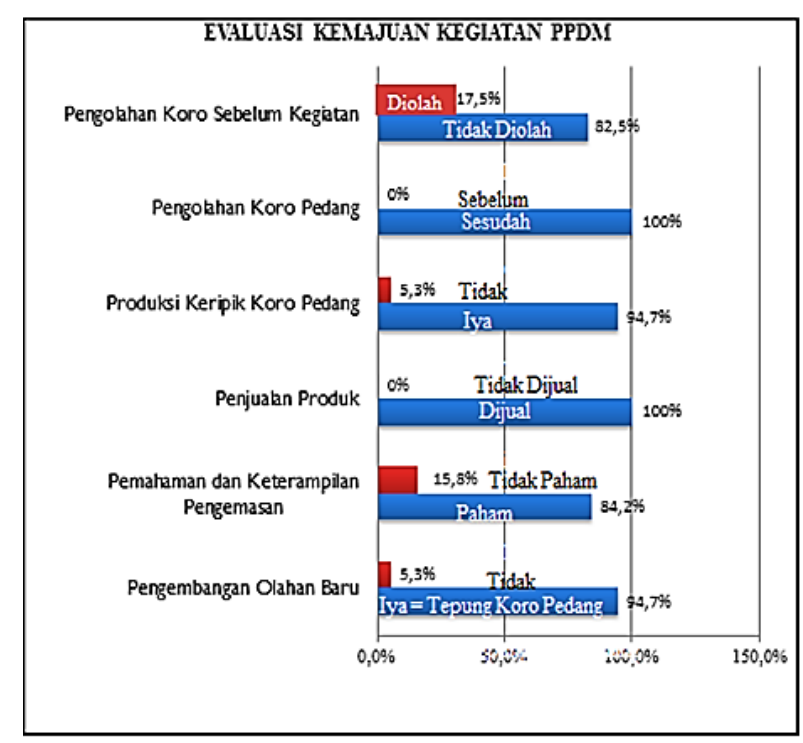

Gambar 4. Hasil evaluasi kemajuan kegiatan PPDM di Desa Tahai Baru Kec. Maliku Kab. Pulang Pisau

Kendala yang dihadapi mitra saat memproduksi keripik tempe adalah ketebalan irisan tempe tidak seragam dan kurang tipis. Hal ini dikarenakan pengirisan tempe dilakukan secara manual dan dikerjakan oleh banyak orang/kelompok. Selain itu bahan baku tempe yang digunakan untuk keripik masih tercium bau tidak enak. Hal ini disebabkan kelompok mitra tidak melakukan penanganan bahan baku cangkordang sesuai prosedur standar yang telah dijelaskan tim pelaksana. Kelompok 
mitra merendam cangkordang hanya 2 hari, sedangkan seharusnya perendaman dilakukan selama 3 hari. Proses perendaman yang tepat dapat menurunkan kandungan asam sianida dalam kacang koro cagkordang seperti pencucian, perendaman dan fermentasi (Susanti et al, 2013; Arianto et al., 2014; Wahono et al., 2016). Bahan baku tempe juga mudah hancur saat diiris. Tempe yang mudah hancur saat diiris disebabkan pada proses pembuatan tempe, adonan tempe hanya secara manual sehingga kepadatan relative bervariasi dan kurang padat. Berat keripik tempe yang dikemas juga seringkali tidak sama. Kelompok mitra mengemas produk keripik tempe tanpa penimbangan, sehingga keripik cangkordang kemasan tidak diketahui beratnya.

Saat ini sudah mulai dilakukan pengenalan produk olahan cangkordang ke konsumen untuk keberlanjutan program. Produk keripik tempe cangkordang mulai diperkenalkan dengan dijual di lingkungan sekitar dan dibawa ke Dinas Sosial Kabupaten Pulang Pisau. Saat ini pula sudah ada pemesanan dari Tim PKK Kabupaten untuk diikutkan sebagai produk olahan pada kegiatan Jambore PKK Kabupaten Pulang Pisau. Keripik tempe cangkordang telah dipasarkan secara online pada media facebook milik mitra. Rencana mitra akan mulai menjual keripik tempe cangkordang secara offline di pasar setempat.

Hampir 94,7\% kelompok mitra sangat menginginkan keberlanjutan kegiatan PPDM ini di desa mereka. Kelompok mitra sangat antusias untuk mengembangkan produk olahan cangkordang berupa tepung cankordang. Menurut kelompok mitra produk tepung cangkordang dengan mudah dapat diaplikasikan pada produk olahan lainnya, seperti cookies, brownis, cake, roti, stik dan olahan lainnya (Gilang et al., 2013; Khotimah et al., 2014; Widiantara, 2018). Selain itu masih adanya kendala teknis seperti ketebalan irisan yang tidak seragam dan kurang padatnya pengemasan tempe merupakan masalah yang harus diatasi dalam keberlanjutan program ini. Keterbatasan pemasaran juga merupakan hal yang harus dicari jalan keluarnya melalui keberlanjutan program agar keagiatan ini benar-benar dapat menuntaskan permasalahan pengembangan produk olahan cangkordang sebagai produk unggulan Desa Tahai Baru, Kecamatan Maliku, Kabupaten Pulang Pisau.

\section{KESIMPULAN}

Dari hasil kegiatan PPDM 2019 dapat diambil kesimpulan yaitu masyarakat desa Tahai Baru sudah memiliki pengetahuan dan keterampilan tentang pengolahan cangkordang (tempe, keripik tempe, nugget dan susu), terjalin hubungan kemitraan antara Universitas Palangka Raya dengan kabupaten Pulang Pisau dalam hal ini Pemerintahan Desa Tahai Baru, dan kelompok mitra yang terlibat dalam kegiatan sudah melakukan pemasaran produk olahan cangkordang berupa tempe, keripik tempe dan nugget cangkordang.

\section{UCAPAN TERIMA KASIH}

Ucapan terimakasih disampaikan kepada LP2M Universitas Palangka Raya yang mendukung kegiatan PPDM melalui Dana Hibah Penelitian PNBP Tahun Anggaran 2019. Ucapan terimakasih juga disampaikan kepada Bapak Guswantoro Kepala Desa Tahai Baru Kec. Maliku Kab. Pulang Pisau dan Dinas Sosial Kab. Pulang Pisau yang telah memberikan ijin dan kesempatan untuk pelaksanaan kegiatan PPDM di wilayah kerjanya.

\section{REFERENSI}

Alsuhendra, A., Ridawati, R. 2017. Pelatihan Pembuatan Kemasan Dan Label Makanan Bagi Pelaku Usaha Makanan Di Desa Jampang, Kecamatan Kemang, Kabupaten Bogor. Sarwahita: Jurnal Pengabdian Kepada Masyarakat. 
14(2):85-93.

https://doi.org/10.21009/sarwahita.142.01

Arianto, A., Nohong, B., Nurhaedah, N. 2014. Analisis Kandungan Asam Sianida (HCN) Pada Kacang Koro Pedang (Canavalia ensiformis) Dengan Menggunakan Lama Perendaman $\mathrm{NaCl}$ Yang Berbeda. Jurnal Galung Tropika. 3(3):186-191. http://dx.doi.org/10.31850/jgt.v3i3.92

Azahari, D.H. 2016. Membangun Kemandirian Pangan Dalam Rangka Meningkatkan Ketahanan Nasional. Analisis Kebijakan Pertanian. 6(2):174195.

http://dx.doi.org/10.21082/akp.v6n2.2008.17 4-195

Dacholfany, M.I. 2018. Pemberdayaan Masyarakat dalam Meningkatkan Mutu Pendidikan NonFormal. Tapis: Jurnal Penelitian Ilmiah. 2(1):4374. https:/ /doi.org/10.32332/tapis.v2i1.866

Diniyah, N., Windrati, W.S., Maryanto, Purnomo, B.H., Wardani, W. 2014. Karakterisasi Tempe Koro Pedang (Canavalia ensiformis (L)) yang Dibuat dengan Variasi Persentase Ragi dan Jenis Pengemas. Warta IHP (Warta Industri Hasil Pertanian). 31(1):1-10. http:/ /dx.doi.org/10.32765/warta/ihp.v31i0 1.2597

Ekafitri, R., Isworo, R. 2014. Pemanfaatan KacangKacangan sebagai Bahan Baku Sumber Protein Untuk Pangan Darurat The Utilization of Beans as Protein Source for Emergency Food. Pangan. 23(2):134-145. http://dx.doi.org/10.33964/jp.v23i2.57

Gilang, R., Affandi, D.R., Ishartani, D. 2013. Karakteristik Fisik dan Kimia Tepung Koro Pedang (Canavalia ensiformis) Dengan Variasi Perlakuan Pendahuluan. Jurnal Technosains Pangan. 2(3):34-42.

Ginting, E. 2002. Teknologi Penanganan Pascapanen dan Pengolahan Ubikayu Menjadi Produk-Antara untuk Mendukung Agroindustri. Buletin Palawija. 4:67-83. http://dx.doi.org/10.21082/bul\%20palawija. v0n4.2002.p67-83

Herawati, H. 2008. Penentuan Umur Simpan Pada Produk Pangan. Jurnal Litbang Pertanian. 27(4):124-130.
Husniah, F.A., Hapsari, T.D., Agustina, T. 2019. Analisis Nilai Tambah Agroindustri Kerupuk Tempe Di Kecamatan Puger Kabupaten Jember. JEPA (Jurnal Ekonomi Pertanian dan Agribisnis). 3(1):195-203.

Indratno, I., Agustina, I.H. 2005. Studi Kemampuan Masyarakat Dalam Pengembangan Ekonomi Lokal Sebagai Upaya Pengentasan Kemiskinan (Studi Kasus Desa Tegalurung Kecamatan Legonkulon Kabupaten Subang). Mimbar: Jurnal Sosial dan Pembangunan. 21(3):416-429. https://doi.org/10.29313/mimbar.v21i3.185

Khotimah, K., Damiati, Ekayani, I.A.P.H. 2014. Uji Kualitas Kue Kering (Kue Satu) Kacang Koro Pedang (Canafalia ensiformis (L) DC) Dengan Teknik Pengolahan Dijemur dan Dioven. Jurnal Bosaparis: Pendidikan Kesejahteraan Keluarga. 2(1):4114. http://dx.doi.org/10.23887/jjpkk.v2i1.4114

Susanti, I., Siregar, N.C., Supriatna, D. 2013. Potensi Kacang Koro Pedang (Canavila ensiformis DC) Sebagai Sumber Protein Produk Pangan. Jurnal Riset Industri. 7(1):1-13.

Wahono, F., Abduh, S.B.M., Nurwantoro, N. 2016. Perubahan Konsentrasi Biomassa, Kadar Asam Sianida (HCN), pH Dan Tampilan Sensori dari Koro Pedang Selama Proses Fermentasi 4 Hari. Jurnal Aplikasi Teknologi Pangan. 5(4):123-128. http:/ /dx.doi.org/10.17728/jatp.194

Widiantara, T. 2018. Kajian Perbandingan Tepung Kacang Koro Pedang (Canavalia ensiformis) dengan Tepung Tapioka dan Konsentrasi Kuning Telur Terhadap Karakteristik Cookies Koro. Pasundan Food Technology Joumal (PFTJ). 5(2):146-153.

http://dx.doi.org/10.23969/pftj.v5i2.1045 